\title{
Peningkatan Aktivitas dan Hasil Belajar Biologi melalui Model Problem Based Learning (PBL) pada Materi Pencemaran Lingkungan Siswa Kelas X SMA Negeri 1 Jatisrono
}

\author{
Evin Hangesti Pradita Dewi ${ }^{1 *}$, Siti Akbari ${ }^{2}$, Anwari Adi Nugroho ${ }^{3}$ \\ ${ }^{123}$ Program Studi Pendidikan Biologi, Universitas Veteran Bangun Nusantara Sukoharjo \\ *Alamat email koresponden : dewievin95@gmail.com
}

\begin{abstract}
Abstrak
Tujuan penelitian ini adalah untuk meningkatkan aktivitas dan hasil belajar siswa dalam pembelajaran Biologi melalui model Problem Based Learning pada siswa kelas X MIPA 3 SMA N 1 Jatisrono Tahun pembelajaran 2017/2018. Metode pengumpulan data menggunakan lembar Observasi, metode tes, dan dokumentasi. Indikator kinerja pada aktivitas individual mencapai $\geq 73,07 \%$ sedangkan hasil belajar siswa secara klasikal mencapai $\geq 88,46 \%$. Aktivitas siswa pada keterampilan (Psikomotor) di siklus I, II, dan III yaitu $(38,46 \%, 69,23 \%, 84,61 \%)$ dan sikap (afektif) untuk siklus I, II, dan III yaitu $(46,61 \%, 61,53 \%, 88,61 \%)$, peningkatan aktivitas siswa siklus III suadah mencapai indikator kinerja keberhasilan $\geq 73,07 \%$. Hasil penelitian siklus I ketuntasan belajar siswa yaitu $65,38 \%$. Pada siklus II ketuntasan belajar siswa mencapai 76, 92\%. Pada siklus III ketuntasan belajar siswa 92,30\%. Hasil belajar sudah memenuhi nilai KKM dan mencapai indikator kinerja keberhasilan $\geq 88,46 \%$. Penelitian ini dapat disimpulkan bahwa penerapan model Problem Based Learning ini dapat meningkatkan aktivitas belajar siswa dan hasil belajar biologi siswa.
\end{abstract}

Kata Kunci: Aktivitas Belajar, Hasil Belajar, Model $P B L$

\section{The Improvement Activities and Learning Outcomes of Biology Through Problem Based Learning (PBL) Model on Environmental Pollution Material for Class X Students Senior High School 1 Jatisrono}

\author{
Evin Hangesti Pradita Dewi ${ }^{1 *}$, Siti Akbari ${ }^{2}$, Anwari Adi Nugroho ${ }^{3}$ \\ ${ }^{123}$ Biology Education Department, Universitas Veteran Bangun Nusantara Sukoharjo \\ *Correspondent's email address :: dewievin95@gmail.com
}

\begin{abstract}
The purpose of this research is to increase the activity and student learning outcomes in Biology learning through the model as Base Learning Program in class X MIPA 3 SMA N 1 Jatisrono in the 2017/2018. Data collection method uses observation sheet, test method, and documentation. Performance indicators on individual activities reach $\geq 73.07 \%$ while student learning outcomes classically reach $\geq 88.46 \%$. Student activities on skills (Psychomotor) in cycle I, II, and III were $(38.46 \%, 69.23 \%, 84.61 \%)$ and attitude (affective) for the cycle I, II, and III, namely $(46.61 \%$, $61.53 \%, 88.61 \%)$, increasing the activity of students in cycle III suadah achieve indicators of success performance $\geq 73.07 \%$. The results of the study in cycle I students 'learning completeness was $65.38 \%$. In the second cycle the completeness of student learning reached 76, 92\%. In the third cycle the student's learning achievement was $92.30 \%$. Learning outcomes have fulfilled the KKM value and achieved success performance indicators $\geq 88.46 \%$. This study can be concluded that the application of the Problem Based Learning model can improve student learning activities and student biology learning outcomes.
\end{abstract}

Keywords: Learning Activities, Learning Outcomes, Model Based Learning. 


\section{PENDAHULUAN}

Biologi adalah ilmu yang pembelajaran segala sesuatu tentang makhluk hidup dan semua kegiatan yang berhubungan dengan makhluk hidup tersebut. Biologi tidak hanya sekedar penguasaan kumpulan pengetahuan berupa konsep, prinsip, dan penemuan saja tapi juga merupakan suatu pengetahuan yang fakta/nyata. Sehingga dalam pembelajaran biologi, seseorang belajar mengenali dan memahami dirinya sendiri maupun yang lain. Proses pembelajaran menekan kepada pemberian pengalaman langsung untuk mengembangkan pemikiran siswa. (Hamalik, 2010).

Pembelajaran biologi dengan standar proses kurikulum 2013 menggunakan pendekatan saintifik dan kontekstual. Proses pembelajaran yang semua terfokus pada kegiatan eksplorasi, elaborasi, dan konfirmasi, pada kurikulum 2013 dilengkapi dengan pembelajaran saintifik yaitu mengamati, menanya, mencoba, menalar,dan menginformasikan. Tujuan Pendidikan Nasional sesuai dengan pencapaian kurikulum 2013 yaitu meningkatkan dan menyeimbangkan pengetahuan (kognitif), keterampilan (psikomotor), dan sikap (afektif). (Kemendikbud, 2013). Sikap diperoleh melalui aktivitas menerima, menjalankan, menghargai, menghayati dan mengamalkan.Pengetahuan diperoleh aktivitas mengingat, memahami, menerapkan, menganalisis, dan mengevaluasi. Keterampilan diperoleh dari aktivitas mengamati, menanya, mencoba, menalar, menyaji, dan menciptakan. (Permendiknas,2003). Kegiatan proses pembelajaran tersebut menunjukan bahwa proses pembelajaran melibatkan siswa 54 secara aktif dengan pembelajaran berpusat pada siswa (student center). Menurut Wahyudi (2015) peran siswa di dalam proses pembelajaran biologi adalah berusaha secara aktif untuk mengembangkan dirinya dibawah bimbingan guru.

Kegiatan pembelajaran biologi di SMA N 1 Jatisrono belum sesuai dengan amanat pembelajaran kurikulum 2013. Hal tersebut dapat diketahui dalam proses pembelajaran biologi hanya memberi penjelasan materi, kemudian siswa mencatat materi. Selain itu selama proses pembelajaran berlangsung hanya sebagian siswa yang memperhatikan dan cenderung pasif dalam mengikuti proses pembelajaran.

Berdasarkan hasil observasi dari 6 kelas untuk X MIPA 3 tergolong masih rendah dan belum memenuhi Kriteria Ketuntasan Minimal (KKM) dibandingkan dengan ke 5 kelas lainnya. Rendahnya hasil belajar biologi ditinjau dari nilai ulangan harian siswa yang memperoleh nilai di atas KKM ( $\geq 70)$ baru 38,46\% ( 10 siswa dari 26) dan yang belum mencapai KKM ( $\geq 70)$ 61,53\% (16 siswa dari 26). Selain nilai ulangan harian, rendahnya hasil belajar kognitif juga ditunjukan dari nilai tengah semester yang diperoleh nilai di atas KKM ( $\geq 70)$ baru 34,61\% (9 siswa dari 26) dan yang belum mencapai KKM ( $\geq 70$ ) yaitu $65,38 \%$ (17 siswa dari 26) Selain dari nilai pengetahuan ada juga dari nilai hanya mendapat $30,76 \%$ (8 siswa dari 26) dan nilai sikap mendapat $30,76 \%$ (8 siswa dari 26).

Hasil belajar kelas $\mathrm{X}$ MIPA 3 memiliki nilai ketrampilan mencapai skor $30,76 \%$ (skala 4) berdasarkan nilai ini maka ada beberapa ketrampilan yang 
belum terberdaya dalam pembelajaran . Pada nilai sikap mencapai skor $30,76 \%$ (skala 4) menunjukan sikap siswa yang belum terberdaya dalam pembelajaran sehingga belum memenuhi skor maksimal 4. Ketercapaian nilai sikap dan ketrampilan yang belum maksimal dikarenakan sistem pembelajaran biologi yang masih konvensional, model yang digunakan guru masih ceramah, sehingga siswa tidak antusias mempelajari biologi. Keaktifan siswa masih sedikit untuk bertanya akan pelajaran yang belum dipahami. Kegiatan mengajar guru belum melibatkan siswa untuk berinteraksi dalam pembelajaran untuk siswa lebih baik dan aktif.

Akar masalah dari rendahnnya hasil belajar biologi di kelas X MIPA 3 adalah pembelajaran yang belum memperdayakan siswa untuk aktif sesuai dengan kurikulum 2013.Solusi untuk mengatasi permasalahaan tersebut salah satunya dengan menerapkan model PBL. $P B L$ adalah pembelajaran yang berpusat pada siswa dengan pendekatan yang memberdayakan siswa untuk melakukan penelitian, mengintegrasikan teori dan praktek, menerapkan pengetahuan serta keterampilan untuk mengembangkan kelayakan pemecahan masalah yang ditemukan. $P B L$ yaitu pembelajaran yang memfokuskan pada siswa menjadi mandiri dan terlibat langsung secara aktif dalam pembelajaran berkelompok.(Astuti, 2013; Sitti, 2014).

Problem based learning (PBL) merupakan pembelajaran yang penyampaiannya dilakukan dengan cara menyajikan suatu permasalahan, mengajukan pertanyaan-pertanyaan, memfasilitasi penyelidikan, dan membuka dialog (Abdullah, 2014). Ciri-ciri PBL yaitu 1) Menggunakan permasalan yang nyata, 2) Pembelajaran berpusat pada penyelesaian masalah, 3) Pembelajaran harus terfokus oleh siswa, 4) Guru berperan sebagai fasilitator.

Model PBL merupakan suatu pembelajaran menggunakan masalah sebagai awal pembelajaran. Karakteristik utama dari $P B L$ adalah siswa fokus pada penyelesaian masalah. (Fitri,2016; Erna,2011). Medriati (2013) menjelaskan bahwa model $P B L$ memiliki pengaruh terhadap aktivitas dan hasil belajar siswa dalam pembelajaran.

Model $P B L$ diterapkan pada mata pelajaran pencemaran lingkungan dengan mengacu pada kurikulum 2013. Pemilihan materi pencemaran lingkungan di sesuaikan dengan karakteristik PBL yang mensyaratkan materi yang kongtektual dan bernuansa masalah nyata. Menganalisis data perubahan lingkungan dan dampak dari perubahan-perubahan lingkungan tersebut bagi kehidupan. Pembelajaran berbasis masalah, dirancang untuk membantu siswa mengembangkan ketrampilan berpikir, menyelesaikan masalah, dan ketrampilan intelektualnya melalui berbagai situasi nyata atau situasi yang disimulasikan, menjadi pelajar yang mandiri.

Berdasarkan rumusan masalah, maka dirumuskan tujuan penelitian adalah meningkatkan aktivitas dan hasil belajar belajar biologi melalui Model Problem Based Learning (PBL) pada materi pencemara lingkungan siswa kelas $X$ MIPA 3 SMA Negeri 1 Jatisrono Tahun Pelajaran 2017/2018. 
METODE

Materi yang digunakan dalam penelitian ini adalah pencemaran lingkungan. Penelitian dilakukan pada siswa SMA N 1 Jatisrono dan mengambil subyek kelas X MIPA 3 tahun pelajaran 2017/2018. Peneliti menggunakan alat bantu seperti silabus, rencana pelaksanaan pembelajaran (RPP), Soal Tes kognitif, lembar observasi siswa dan guru. Penelitian ini menggunakkan III siklus yaitu siklus I, siklus II dan siklus III yang masing-masing siklus melalui tahap perencanaan, pelaksanaan tindakan, pengamatan dan refleksi.

Teknik pengumpulan data ada tiga metode antara lain seperti, Lembar Observasi dalam penelitian ini, metode observasi digunakan untuk menilai aktivitas guru dan aktivitas siswa yang akan dilakukan dengan mengamati seluruh proses pembelajaran dikelas, Metode Tes digunakan untuk mengetahui tingkat perkembangan atau peningkatan hasil belajar siswa setelah diterapkan model pembelajaran Problem Based Learning $(P B L)$ melalui tes Esay yaitu dengan Validitas, Tingkat Kesukaran Butir, Daya Pembeda Butir, dan uji realibilitas.

Dalam peneliti ini, indikator yang menjadi pedoman keberhasilan adalah peningkatan hasil belajar siswa yang dilihat dari hasil tes siswa melalui penerapan model pembelajaran Problem Based Learning (PBL). Indikator keberhasilan dalam penelitian ini adalah 1) hasil tes pengetahuan (kognitif) siswa yang tuntas belajar minimal 84,61\% (22 dari 26 siswa) ketuntasan diukur dari nilai $\mathrm{KKM} \geq$ 70. 2) hasil observasi sikap (afektif) mencapai rata-rata skor 12,2 minimal
73,07\% (19 dari 26 siswa). 3) hasil observasi ketrampilan (psikomotor) atau aktivitas mencapai rata-rata 10,2 minimal 73,07\% (19 dari 26 siswa).

\section{HASIL DAN PEMBAHASAN}

Penelitian ini dilakukan di SMA Negeri 1 Jatisrono, Kabupaten Wonogiri, yakni di kelas MIPA X IPA 3 tahun ajaran 2017/2018. Dimana ketuntasan kelas hanya mencapai 38,46\% (10 dari 26 siswa) yang tergolong masih rendah yang belum memenuhi nilai Kriteria Ketuntasan Minimal (KKM) yaitu 70 jika dibandingkan 5 kelas yang lain.

Suasana kelas waktu mendapatkan pelajaran biologi, guru hanya memberikan penjelasan materi. Siswa mencatat materi, dalam pembelajaran berlangsung hanya sebagian siswa yang memperhatikan dan cenderung pasif dalam mengikuti proses pembelajaran. Keaktifan siswa masih sedikit untuk bertanya dalam pelajaran yang belum dipahami. Guru belum melibatkan siswa untuk beriteraksi dengan baik/siswa harus aktif sesuai dengan kurikulum 2013. Sehingga mengakibatkan rendahnya aktivitas. Berdasarkan hasil yang diperoleh nilai pada pra siklus/sebelum tindakan dapat dilihat dari tabel 1.

Tabel 1. Hasil Belajar Siswa pada Pra Siklus

\begin{tabular}{lllll}
\hline & & & & Rata- \\
No & Ketuntasan & Jumlah \\
Belajar & Siswa & $\begin{array}{l}\text { Presentase } \\
(\%)\end{array}$ & $\begin{array}{l}\text { rata } \\
\text { Nilai } \\
\text { Kelas }\end{array}$ \\
\hline 1 & Tuntas & 10 & $38,46 \%$ & 60,34 \\
2 & Tidak Tuntas & 16 & $61,53 \%$ & \\
\hline
\end{tabular}

Tabel 2. Aktivitas Siswa Pra Siklus

\begin{tabular}{llll}
\hline \multirow{2}{*}{ No } & Aktivitas & Jumlah & Presentase (\%) \\
& Siswa & Siswa & \\
\hline 1 & Aktif sekali & 8 & $30,76 \%$ \\
2 & Cukup Aktif & 12 & $46,15 \%$ \\
3 & Kurang Aktif & 6 & $23,07 \%$ \\
\hline
\end{tabular}


Berdasarkan tabel 1 dan tabel 2 dapat disimpulkan bahwa dari hasil perolehan Pra Siklus dari 26 siswa yang dapat memenuhi Kriteria Ketuntasan Minimal (KKM) yaitu 70 mencapai $38,46 \%$ (10 dari 26 siswa), sedangkan 61,53\% (16 dari 26 siswa) mendapat nilai dibawah KKM dan aktivitas siswa yang mencapai 30,76\% (8 dari 26 siswa aktif sekali), 46,15\% (12 dari 26 siswa cukup aktif) dan 23,07\% (6 dari 26 siswa kurang aktif) yang belum memenuhi indikator kinerja yaitu 73,04\% (22 dari 26 siswa ). Selain dapat dilihat dari tabel 3 dan tabel 4, hasil belajar siswa juga dapat dilihat dari grafik gambar 1 dan gambar 2.

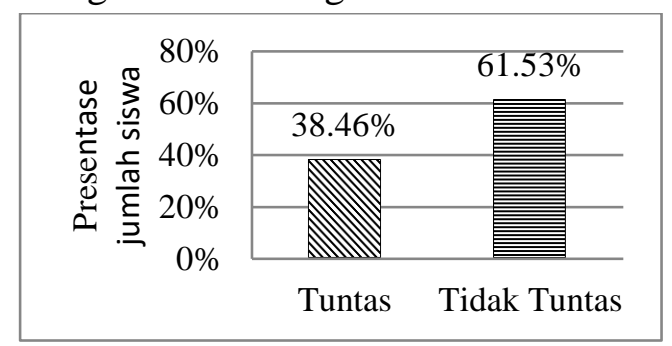

Gambar 1. Grafik Hasil Belajar Siswa pada Pra Siklus

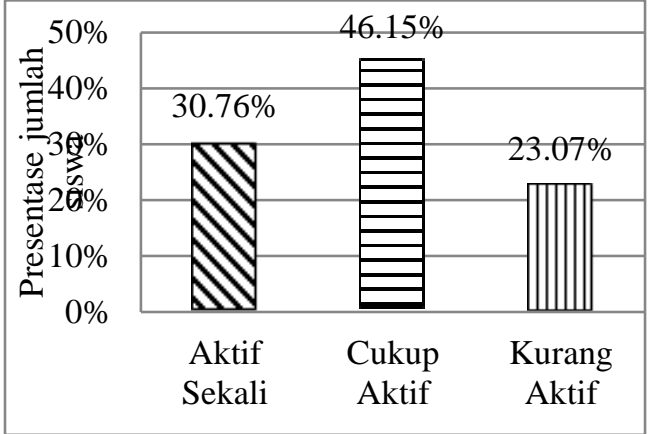

Gambar 2. Grafik Aktivitas Siswa pada Pra Siklus

Berdasarkan hasil observasi yang dilakukan pada saat pembelajaran biologi, menunjukkan bahwa hasil belajar kognitif dan aktivitas/psikomotor yang diperoleh siswa kelas X MIPA 3 SMA Negeri 1 Jatisrono sangat rendah. Rendahnya nilai dan aktivitas siswa dipengaruhi oleh: siswa kurang memperhatikan materi yang disampaikan oleh guru, takut untuk bertanya mengenai materi yang belum dipaham. Hal ini terjadi karena proses pembelajaran biologi berlangsung secara konvensional. Sehingga sebagian siswa pasif dan belum terberdayanya untuk melibat dalam pembelajaran.

\section{Perbandingan Hasil Siklus I, II, III}

Berikut ini tabel perbandingan peningkatan hasil belajar siswa dari siklus I, siklus II, dan siklus III.

Tabel 3. Perbandingan Hasil Afektif Siswa, Aktivitas/psikomotor Siswa, Hasil Belajar Kognitif Siklus I, Siklus II, dan Siklus III

\begin{tabular}{|c|c|c|c|c|c|c|}
\hline No & $\begin{array}{c}\text { Perbandingan Hasil } \\
\text { Belajar }\end{array}$ & Tindakan & $\begin{array}{c}\text { Presentase } \\
(\%)\end{array}$ & $\begin{array}{l}\text { Indikator } \\
\text { Kinerja }\end{array}$ & $\begin{array}{c}\text { Rata-rata } \\
\text { Nilai Kelas }\end{array}$ & Keputusan \\
\hline 1 & $\begin{array}{l}\text { Hasil Observasi belajar } \\
\text { Afektif }\end{array}$ & Siklus I & $46,61 \%$ & \multirow{5}{*}{$73,07 \%$} & & \multirow{6}{*}{$\begin{array}{l}\text { Belum } \\
\text { Tercapai } \\
\text { Belum } \\
\text { Tercapai } \\
\text { Tercapai } \\
\text { Belum } \\
\text { Tercapai } \\
\text { Belum } \\
\text { Tercapai } \\
\text { Tercapai }\end{array}$} \\
\hline \multirow{4}{*}{2} & \multirow{4}{*}{$\begin{array}{l}\text { Hasil Observasi belajar } \\
\text { aktivitas/psikomotor }\end{array}$} & Siklus II & $61,23 \%$ & & & \\
\hline & & Siklus III & $88,61 \%$ & & & \\
\hline & & Siklus I & $38,46 \%$ & & & \\
\hline & & Siklus II & $69,23 \%$ & & & \\
\hline 3 & Penilaian hasil belajar & $\begin{array}{l}\text { Siklus III } \\
\text { Siklus I }\end{array}$ & $\begin{array}{l}84,61 \% \\
65,38 \%\end{array}$ & $84,61 \%$ & 70,76 & \\
\hline
\end{tabular}




\begin{tabular}{|c|c|c|c|c|c|c|}
\hline \multirow[t]{4}{*}{ No } & \multirow{4}{*}{$\begin{array}{l}\text { Perbandingan Hasil } \\
\text { Belajar } \\
\text { kognitif }\end{array}$} & Tindakan & \multirow[t]{2}{*}{$\begin{array}{c}\text { Presentase } \\
(\%)\end{array}$} & \multirow[t]{2}{*}{$\begin{array}{c}\text { Indikator } \\
\text { Kinerja }\end{array}$} & \multirow[t]{2}{*}{$\begin{array}{c}\text { Rata-rata } \\
\text { Nilai Kelas }\end{array}$} & Keputusan \\
\hline & & & & & & Tercapai \\
\hline & & Siklus II & $76,92 \%$ & & 76,77 & $\begin{array}{l}\text { Belum } \\
\text { Tercapai }\end{array}$ \\
\hline & & Siklus III & $92,30 \%$ & & 77,04 & Tercapai \\
\hline
\end{tabular}

Berdasarkan penilaian afektif memiliki 4 aspek yang diamati yaitu: Disiplin, kolaborasi, komunikasi, dan leterasi memahami petunjuk kerja. Pelaksanaan pembelajaran dari siklus ke siklus yang lain mengalami peningkatan. Pada siklus I penilaian terhadap aspek afektif 46,61\% (12 dari 26 siswa) mendapatkan kategori baik sekali, siklus II penilaian terhadap aspek afektif 61,23\% (16 dari 26 siswa) mendapatkan kategori baik, siklus III penilaian terhadap aspek afektif 88,61\% (23 dari 26 siswa) mendapatkan kategori baik dengan indikator kinerja dengan presetasi 73,07\% (19 dari 26 siswa) yang mendapatkan kategori baik.

Selain dapat dilihat dari tabel 3, perbandingan hasil afektif siswa juga dapat dilihat dari grafik gambar 3.

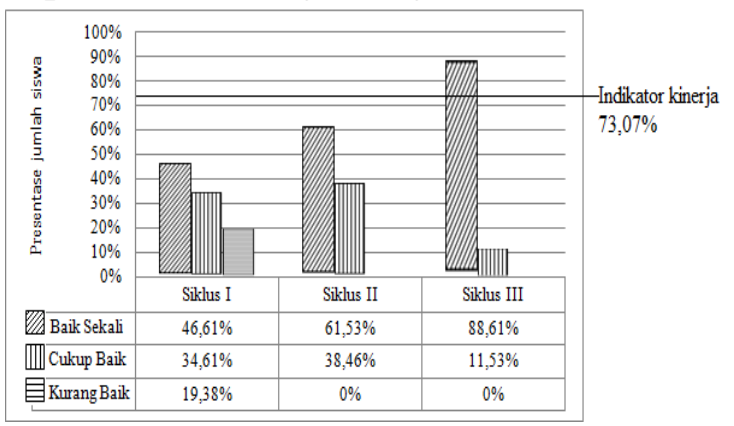

Gambar 3. Afektif Siswa Siklus I, Siklus II dan Siklus III

Berdasarkan penilaian aktivitas/psikomotor memiliki 3 aspek dari pelaksanaan pembelajaran dari siklus ke siklus yang lain mengalami peningkatan. Pada siklus I penilaian terhadap aspek aktivitas/psikomotor $38,46 \%$ (10 dari 26 siswa) mendapatkan 58 kategori aktif sekali, siklus II penilaian terhadap aspek aktivitas/psikomotor 69,23\% (18 dari 26 siswa) mendapatkan kategori aktif sekali, siklus III penilaian terhadap aspek aktivitas/psikomotor 84,61\% (22 dari 26 siswa) mendapatkan kategori aktif sekali dengan indikator kinerja dengan presentase 73,07\% (19 dari 26 siswa) yang mendapatkan kategori aktif sekali dalam pembelajaran biologi.

Selain dapat dilihat dari tabel 3, perbandingan hasil aktivitas/ psikomotor siswa juga dapat dilihat dari grafik gambar 4.

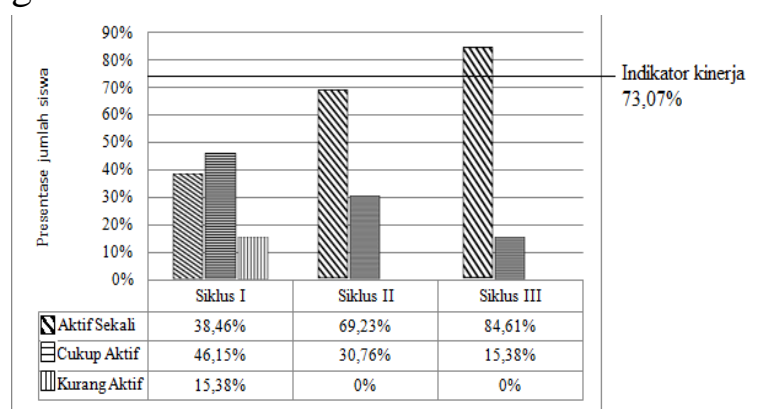

Gambar 4. Aktivitas/ psikomotor

Siswa Siklus I, Siklus II, dan Siklus III

Berdasarkan hasil belajar kognitif siswa dari pelaksanaan pembelajaran dari siklus ke siklus yang lain mengalami peningkatan. Dari indikator kinerja $84,61 \%$ (22 dari 26 siswa) yang mendapatkan kategori tuntas. Pada siklus I hasil belajar mendapatkan 65,38\% (17 dari 26 siswa) mendapatkan kategori tuntas, siklus II penilaian hasil belajar mendapatkan 76,92\% (20 dari 26 siswa) mendapatkan kategori tuntas, siklus III penilaian hasil belajar mendapatkan 
92,30\% (24 dari 26 siswa) mendapatkan kategori tuntas. Perbandingan hasil belajar kognitif siswa juga dapat dilihat dari grafik gambar 5 .

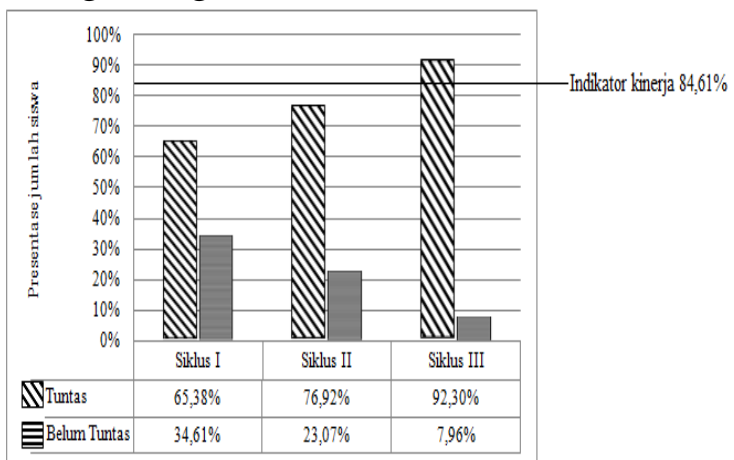

Gambar 5. Grafik Hasil Belajar Kognitif Siswa Siklus I, Siklus II, dan Siklus III

Berdasarkan perbandingan hasil belajar kognitif siswa dan penelitian tindakan kelas, dari siklus I sampai III mengalami peningkatan. Telah terlaksana dalam 4 aspek yang dinilai dari afektif, 3 aspek yang dinilai dari aktivitas/psikomotor dan hasil belajar kognitif mencapai indikator kinerja, dengan menerapkan model pembelajaran Problem Based Learning kelas X MIPA 3 SMA N 1 Jatisrono dapat meningkat.

$\begin{array}{ccc}\text { Peningkatan } & \text { Aktivitas } & \text { Siswa } \\ \text { dengan Penerapan } & \text { Problem } & \text { Based }\end{array}$
Learning terlihat dari kenaikan presentase aktivitas siswa dalam pembelajaran di kelas. Setelah dilaksanakan tindakan di kelas X MIPA 3 SMA Negeri 1 Jatisrono, terjadi peningkatan hasil aktivitas/psikomotor dan afektif. Pada siklus I, siklus II dan siklus III.Dalam penelitian ini hasil belajar dari aspek aktivitas/ psikomotor dapat dinilai dari indikator yaitu: keaktifan memecahkan masalah dipembelajaran, mengkomunikasikan hasil diskusi/ presentasi, keterampilan penggunaan alat dan bahan, dan 4 aspek afektif dapat dinilai dari indikator yaitu: disiplin, kolaborasi, komunikasi dan literasi memahami petunjuk kerja. Pada siklus I mencapai $38,46 \%$ dengan kategori aktif sekali dan $46,61 \%$ dengan kategori baik sekali, dilihat dari penggunaan model Problem Based Learning saat pembelajaran. Tahap pengembangan dan presentasi siswa yang menyampaikan hasil diskusi dengan suara lantang dan lancar (aspek mengkomunikasikan hasil diskusi dan presentasi) dan pada tahap orientasi siswa tidak bolos dalam pelajaran dan tahap investigasi siswa mengerjakan tugas yang diberikan oleh guru dengan baik (aspek disiplin dalam pembelajaran). Kemudian pada siklus II meningkat menjadi $69,23 \%$ dengan kategori aktif sekali, 61,53\% dengan kategori baik sekali, dilihat dari model Problem Based learinng saat pembelajaran berlangsung.

Tahap orientasi siswa tidak bolos, datang tepat waktu (aspek disiplin saat pembelajaran), tahap investigasi siswa bisa menggunakan alat dan bahan (aspek keterampilan penggunaan alat dan bahan), tahap pengorganisasian siswa bisa berkerja sama saat pembelajaran berlangsung dan tidak ragu untuk mengutarakan ide atau gagasan kepada teman (aspek kolaborasi saat pembelajaran dan komunikasi saat pembelajaran). Pada siklus III terjadi peningkatan persentase sebesar $84,61 \%$ dengan kategori aktif sekali dan 88,61\% dengan kategori baik sekali. Dilihat pada tahap-tahap model Probelm Based Learnig saat pembelajaran berlangsung. Tahap siswa tidak ramai saat pembelajaran (aspek disiplin), siswa berpartisipasi dalam mengajukan pertanyaan pada guru (aspek keaktifan dalam memecahkan masalah), 
tahap investigasi siswa mendengarkan dan membaca petunjuk dari guru membaca LKS (aspek literasi memahami petunjuk kerja), siswa menuliskan hasil percobaan sesuai percobaan (aspek keterampilan penggunaan alat dan bahan), tahap pengembangan dan siswa berpartisipasi dalam mengajukan pertanyaan dan memberi solusi dari teman dan guru (aspek keaktifan dalam memecahkan masalah dikelas), siswa sudah menghargai pendapat teman (aspek komunikasi saat pembelajaran). Dengan demikian, hasil aktivitas belajar siswa telah memenuhi indikator keberhasilan yang telah di tetapkan, yaitu persentase $\geq 73,07 \%$.

Peningkatan aktivitas belajar siswa dari siklus I sampai siklus III menunjukkan bahwa, penerapan model Problem Based Learning pada materi pencemaran lingkungan di SMA Negeri 1 Jatisrono dapat meningkatkan aktivitas belajar siswa. Penelitian oleh (Astuti, 2013; Hadijah, 2014; Widodo, 2013; Wahyudi, 2015) mengatakaan bahwa dengan meningkatnya aktivitas belajar selama proses pembelajaran berlangsung, sikap akan tumbuh dalam diri siswa dengan sendirinya ketika siswa membiasakan diri lebih baik seperti disiplin. Dan beberapa siswa yang tidak menyimak penjelasan guru dan kurang aktif dalam kegiatan diskusi pada siklus I disebabkan karena kemauan untuk belajar masih kurang. Namun pada siklus II aktivitas siswa mulai meningkat, hal ini disebabkan karena dorongan oleh guru akan pentingnya belajar. Hasil penelitian Nugroho \& Hanik (2015) menyatakan bahwa pembelajaran yang mengakomodasi kerjasama dan interaksi siswa dapat meningkatkan aktivitas belajar.
Hasil kognitif belajar Siswa dengan Penerapan Problem Based Learning tindakan siklus I belum tampak peningkatan dari hasil kognitif belajar, sebagian besar siswa masih belum melakukan pembelajaran dengan memecahkan masalah melalui model Problem Based Learning. Penyebab terjadinya masalah ini antara lain (1) siswa belum terbiasa dengan model pembelajaran yang digunakan; (2) siswa saat pembentukan kelompok berebut menjadikan suasana kelas ramai dan belum berani untuk bertanya; (3) kurangnya siswa terlibat langsung dalam percobaan. Pada pelaksanaan tindakan siklus I terlihat pada tahap Problem Based Learning yaitu orientasi, analisis dan evaluasi saat mengerjakan post tes.

Pelaksanaan tindakan pada siklus II sudah nampak peningkatan, yaitu guru sudah terbiasa dengan langkah-langkah model Problem Based Learning, walau masih ada kekurangan dalam pembelajaran. Sebelumnya siswa masih belum terlibat sepenuhnya dalam mengamati percobaan dan belum aktif dalam memecahkan masalah yang diberikan teman. Akhirnya siswa dapat mengerti dan tugas yang diberikan menjadi mudah di kerjakan. Pelaksanaan pada siklus III tampak jelas terjadi peningkatan aktivitas atau ketrampilan dan sikap belajar siswa. Siswa sudah aktif dalam melakukan pengamatan dan mengumpulkan informasi serta mengerjakan post test dengan baik.

Pada hasil belajar siswa pada pembelajaran biologi materi pencemaran lingkungan menunjukkan bahwa pembelajaran biologi dengan menerapkan model Problem Base Learning dapat meningkatkan hasil kognitif belajar siswa 
di setiap siklusnya. Sesuai dengan hasil penelitian (Astuti, 2013; Mardiati,2013; Fauzan, 2017; Fitri, 2016) juga menunjukan peningkatan peserta didik diharapkan mempunyai pemahaman tentang apa yang dipelajari, mengikuti pembelajaran dalam memecahkan masalah, dan hasil belajar kognitif dikembangkan dari hasil post test peserta didik.

\section{KESIMPULAN DAN SARAN}

\section{Kesimpulan}

Berdasarkan hasil yang di peroleh dari penelitian yang telah dilakukan dengan subjek siswa kelas X MIPA 3 SMA Negeri 1 Jatisrono dapat disimpulkan bahwa penerapan model Problem Based Learning (PBL) dapat meningkatkan aktivitas belajar biologi siswa dari segi psikomotor (Keterampilan) dan afektif (sikap). Selain itu juga dapat meningkatkan hasil belajar biologi siswa dari segi kognitif.

\section{Saran}

Adapun saran-saran yang penulis kemukakan sehubungan dengan penelitian ini adalah 1) bagi siswa diharapkan siswa dapat melakukan kegiatan percobaan kaitan dengan berpendapat dalamdiskusi kelompok misalnya percobaanyang memberikan masalah sehingga dapat berfikir kritis dan inovatif, 2) bagi guru diharapkan guru dapat terus mengembangkan kreativitas dan potensinya dalam menciptakan suasana pembelajaran yang menyenangkan bagi siswa dan membantu guru dalam mempelajari materi lebih mudah dan menyenangkan menggunakan, 3) bagi sekolah sarana dan prasarana yang menunjang pelaksanaan pembelajaran dengan menerapkan model Problem Based Learning, merupakan wujud dukungan terhadap pelaksanaan pembelajaran di kurikulum 2013yang baru ini karena berpusat pada siswa dan guru hanya sebagai fasilitator dalam kelas, 3) bagi peneliti saran yang dapat peneliti berikan adalah Model
Problem Base Learning perlu di sosialisasikan agar lebih sering di terapkan dalam pembelajaran di sekolah untuk meningkatkan aktivitas belajar siswa dan hasil belajar siswa. Serta melakukan percobaan dalam setiap pembelajaran agar siswa mudah mengingat dan berfikir kritis dalam pembelajaran.

\section{UCAPAN TERIMAKASIH}

Penelitian ini dapat selesai dengan baik karena bantuan dari berbagai pihak. Oleh karena itu penulis mengucapkan terima kasih kepada kepala sekolah SMA N 1 Jatisrono Sentot, S.Pd, M.Pd., atas izin yang diberikan, Supriyanto S.Pd selaku guru biologi yang telah banyak membantu dalam penelitian serta siswa siswi kelas $\mathrm{X}$ MIPA 3 SMA N 1 JatisrnoTahun Pelajaran 2017/2018.

\section{DAFTAR PUSTAKA}

Abdullah, Ridwan. (2014). Pembelajaran Santifik untuk Implemetasi Kurikulum 2013. Jakarta : Bumi Aksa.

Ariyanto, Dedy. (2017). Strategi pembelajaran Problem Based Lerning dan motivasi belajar terhadap hasil belajar kognitif pada mata kuliah ilmu kealaman dasar.Volume.3. No 2.Diakses dari jurnalAriyanto. Volume 3.

Astuti, Retno Puji.(2013). Peningkatan Aktivitas dan Hasil Belajar Melalui PBL Pada Siswa Kelas X6 SMA Negeri 4 Pekalongan Tahan 2012/2013.Volume.42. No 2. Diakses dari jurnal Astuti.Volume 24.

Batdi, Mariana. (2014). Upaya Peningkatan Aktivitas dan Hasil Belajar Biologi Siswa Menggunakan Model Problem Based Learning (PBL) Pada Materi Pokok Pencemaran Lingkungan Kelas X SMA Swasta Sidomarem.Volume.1. No 1.Diakses dari jurnal Batdi.Volume 1.

Erna,Widiyawati. (2011). Penerapan Model Pembelajaran Bsebases Masalah( Problem Based Learning) Untuk Meningkatkan Pemahaman Konsep Mata Pelajaran Biologi Di MAN 3 Malang.Volume 1 No 2.Diakses dari jurnal Erna. Volume 1

Fauzan, Maarut, Abdul Gami, Muhammad Syukri. (2017). Penerapan model Problem Based Learning pada pembelajaaran materi tata surya 
untuk mengkatkan hasil belajar siswa. Volume 05. No 1.Diakses dari jurnal Fauzan .Volume 5.

Fitri. (2016). Penerapan Model PBL Pada Pelajaran Biologi Untuk Meningkatkan Kompetensi Dan Kemampuan Berpikir Kritis Siswa Kelas X Kerangka Berpikir SMA Negeri 19 Bandung tahun pelajaran 2014/2015.Diakses dari jurnal Fitri.Volume 1.No 1. Diakses dari jurnal Fitri. Volume 1.

Hamalik, Oemar. (2010). Proses Belajar Mengajar. Jakarta : Bumi Aksara.

Hadijah, Sitti. (2014). Peningkatkan moitvasi, aktivitas, dan hasil belajar siswa pada materi ekosistem melalui penerapan model pembelajaran Problem Based Learning kelas VII $_{F}$ SMP N 3 Palopo. Volume01. No 1.Diakses dari jurnal Hadijah. Volume 1.

Kemedikbud. (2013). Premendikbud No. 56 tentang Standar Proses pendidikan dasar dan menengah. Jakarta: Kementrian Pendidikan dan Kebudayaan.

Medriati, R. (2013). Upaya Peningkatan Hasil Belajar Fisika Siswa Pada Konsep Cahaya Kelas VII6 Melalui Penerapan Model Pembelajaran Problem Based Learning (PBL) Berbasis Laboratorium di SMPN 14 Kota Bengkulu. Volume. 3. No 1. Diakses dari jurnal Medriati .Volume 3.
Nugroho, A. A., \& Hanik, N. R. (2015, November). A Studi on High Plant Systems Course with Active Learning in Higher Education Through Outdoor Learning to Increase Student Learning Activities. In Proceeding Biology Education Conference: Biology, Science, Enviromental, and Learning (Vol. 12, No. 1, pp. 551-556).

Putra, Muhammad. (2012). Penerapan model Problem Based Learning (PBL) untuk meningkatkan kebiasaan berpikir luas pada konsep pencemaran lingkungan. Volume 06. No.2. Diakses dari jurnal Putra, Muhammad. Volume 6.

Wahhyudi, Adi, Marjono, Harlita. (2015). Pengaruh Problem Based Learning terhadap keterampilan proses sain dan hasil belajar biologi siswa kelas X SMA N Jumapolo Tahun Pelajaraan 2013/2014. Volume 04. No.1. Diakses dari jurnal Wahhyudi, adi, Marjono, Harlita. Volume 04

Widodo, Lusi Widayanti. (2013). Peningkatan Aktivitas Belajar Dan Hasil Belajar Siswa Dengan Metode Problem Based Learning Pada Siswa Kelas Vll A Mts Negeri Donomulyo Kulon ProgoJurnal Fisika Indonesia. Volume. 97, No.49.Diakses dari jurnal Widodo, Lusi Widayarti .Volume 97. 